\author{
Malgorzata Suświllo, PhD, Associate Professor \\ Faculty of Social Sciences, University of Warmia and Mazury in Olsztyn \\ Department of Teaching and Early Education \\ Republic of Poland \\ psus@uwm.edu.pl
}

\title{
GIFTED STUDENT IN A POLISH SCHOOL IN THE PERCEPTION OF TEACHERS, PARENTS AND THE CHILD: THE INTERPRETATIVE RESEARCH
}

\begin{abstract}
This paper presents research into the social, emotional, and academic functioning of gifted students in the classroom. An outline is provided of the theoretical foundations of the problem, starting with its definition and presentation of giftedness models. It then discusses the functioning of gifted students in the perspective of other authors. This study aims to examine the performance of a gifted student in a class in the selected state primary school, based on the perception of teachers, parents and the child in question. The study uses the qualitative strategy and the interpretational approach. Gifted students (six cases) were nominated by their form teachers. Empirical data collected during free-form and unstructured interviews were subjected to a qualitative analysis. By arranging the data from interviews with parents, teachers, and gifted students themselves, a picture was constructed of their functioning. To do that, metaphorical categories of gifted students were separately created for each scope (social, emotional, academic). The study analyses the performance of gifted students and compares them to theoretical assumptions.
\end{abstract}

Keywords: educational functioning, emotional functioning, giftedness models, parents, social functioning, teachers

\section{INTRODUCTION}

The functioning of a gifted student in class presents sociological, psychological and pedagogical challenges. The sociological aspect refers to social behaviour in relationships with peers and teachers. The psychological aspect involves the emotional and volitional performance in the school setting and elsewhere. The pedagogical aspect concerns the academic functioning of the student, including his or her academic achievements. In all of these aspects, a gifted student poses a challenge to the teacher, the parents and himself or herself. The teacher's 
understanding of the child's needs and functioning relies on conventional wisdom, frequently marred by myths. This mentality leads to defective social relationships in class (emerging violence), underperformance, and a sense of rejection (cases of depression and suicide). Paula Olszewski-Kubilius and Dana Thomson (2015) distinguish two frameworks of the approach to gifted students which affect their further education. One is referred to as the traditional approach, and the other - as talent development. Although both consider individual differences between children, measured with tools such as IQ tests, they differ in their developmental focus on the nature of talent. The traditional approach regards exceptional giftedness and/or high intelligence as static features - something you either have or not. The talent development perspective sees giftedness and talent as elastic and evolving over time. The traditional developmental approach is also discernible in the work of other researchers (Nęcka, 2003). However, psychology typically distinguishes between the elitist and egalitarian approach to giftedness. The elitists view the phenomenon in a one-dimensional perspective, mostly through the lens of the intelligence quotient (IQ) and estimate the percentage of gifted and talented children at 3-5\% (Marland 1972, as in Sisk, 1987). In contrast, the egalitarians assume that this group encompasses $25 \%-30 \%$ of the population (Limont, 2004). Thus, the egalitarian framework opens up a door for pedagogues to hone the talents of their students.

This paper aims to present the social, emotional and educational functioning of gifted students in the Polish school. The findings are based on qualitative research involving a series of case studies carried out in a small-town school in north-eastern Poland. The study group includes pupils in lower grades of primary school, which reflects the author's belief that the functioning mechanisms of a gifted student at this educational stage may substantially affect his or her performance during subsequent phases of life and education. At times, the term 'giftedness' is used interchangeably with words such as 'ability', 'aptitude' or 'talent'. Polish psychologists (Partyka, 1999; Limont, 1994, 2012; Nęcka, 2003; Giza, 2006) describe giftedness as a psychological property which turns every person into an individual equipped with exceptional skills related to the acquisition and processing of knowledge about the surrounding world. Mirosława Partyka $(1999$, p. 9) understands giftedness as individual differences which make some people learn faster while others encounter more difficulties, even if they share the same knowledge, general condition, motivation and external conditions. This definition follows the cognitive approach to giftedness, which regards the phenomenon as intellectual effort in which information processing relies on psychological operations in the brain.

Following an investigation into a variety of concepts, Maria Ledzińska distinguished four definition types of giftedness: giftedness as a type of individual differences which account for the varying levels of achievement in identical or similar conditions, without identifying the origin of those differences [...], 
giftedness as an actual ability to perform specific tasks or a potential aptitude, or the maximum possible level of capacity that can be achieved with innate predispositions, giftedness as a relatively stable characteristic of cognitive processes which result in a high level of achievement in task solution (the essence of the cognitive approach) andgiftedness as basic individual qualities allowing us to develop other skills (Ledzińska, 2008, pp. 52-53).

Many definitions refer to multiple types of giftedness, including general high ability, domain-specific talents, creative, elementary, natural, complex "specifically human" or real aptitude (Limont 1994). The literature also distinguishes a range of giftedness models, although their detailed descriptions are unnecessary to list here. Limont (2005) differentiates four types of functioning models: 1) models of general giftedness, 2) models of domain-specific giftedness, 3) systems models and 4) developmental models.

Models of general giftedness emerged during the first wave of research into intelligence which generally equated giftedness with intelligence. Otherwise stated, the level of intelligence is the principal criterion for labelling a person as gifted (Nęcka, 2003). These models frame intelligence as an individual personality disposition for effectively managing the processes of learning and acting. These processes have a bearing on all areas of human activity, regardless of their degree of specificity (Nęcka, 2003).

Models of domain-specific giftedness mainly rely on factor analysis. They assume the existence of general intelligence ( $g$ factor) which accounts for giftedness in the scope of the basic cognitive processes and the specific $s$ factor which determines domain-specific giftedness (such as musical giftedness). However, those models are not uniform. The so-called hierarchical models regard the $g$ factor (general intelligence) as superordinate in relation to the $s$ factor (domain-specific giftedness), whereas the models with equal factor loadings accord the same importance to all factors. An interesting example from the latter group is the concept formulated by Wiesława Limont, which presents the structures of domain-specific giftedness based on the assumption that "human endeavour relates to a variety of areas, domains, disciplines, and fields of activity" (Limont, 2012, p. 49). The domains distinguished by the author comprise multiple disciplines and those, in turn, comprise multiple specialities and specialisations. This model also involves the theory of multiple intelligences conceived by Howard Gardner (2000), which distinguishes nine types of intelligence (domain-specific giftedness). According to Gardner, every person has a unique intelligence profile, which includes high levels of various domain-specific abilities. Even though the author refutes the existence of general intelligence, the concept undoubtedly shows educational utility due to its developmental character.

Systems models take into account the concept of domain-specific abilities but embrace them as a structure of interrelated and interreacting components. According 
to Limont (2012), this group includes the theories of Joseph S. Renzulli, Robert J. Sternberg and the concept founded on the theory of positive disintegration, of lesser global recognition but utmost importance, established by Polish psychologist Kazimierz Dąbrowski. Renzulli's Three-Ring Model ranks among the most popular frameworks in English literature. It is the cornerstone for the formulation of other models (Limont, 1994, 2012) and the concept of student giftedness assessment (Uszyńska-Jarmoc \& Kunat, 2018). Renzulli observes a close interaction between three basic clusters of human traits displayed by the exceptionally gifted: above-average intelligence or above-average domain-specific abilities, high level of task commitment, and a high level of creativity understood as divergent thinking abilities. All of the clusters carry equal importance in the making of a gifted individual. What seems crucial for the education of gifted children is the assertion that even small children are capable of task commitment. Sternberg, the founder of the investment theory (as in Limont, 2012) lists the following factors of exceptional abilities: wisdom, intelligence, creativity and a synthesis of the former three elements. Note that Sternberg's concept is used as a model of creativity which combines the intellectual component with personality-related considerations and the sociocultural context. Dąbrowski's theory of positive disintegration comprises three factors: 1) constitutional and hereditary overexcitability; 2) the impact of the social environment on the development of an individual, and 3) internal dynamics which allow individuals to make informed and autonomous decisions concerning their growth through "self-education, creative negation or affirmation of their aspirations and external influences" (Limont, 2012, p. 63). It seems important to continue deliberations on gifted students in the light of Dąbrowski's assertion that gifted people typically exhibit psychological overexcitability, which manifests itself in three dimensions: intellectual, imaginational and emotional.

Developmental models include concepts such as Franz J. Mönks's multifactor model of giftedness which considers the interrelations between various components of giftedness (general or domain-specific, motivational and personality-related), embedded in principal environmental settings (family, school, and peers), which jointly affect and define the functioning of an individual (as in Limont, 2012). This group also comprises the model developed by Abraham J. Tannenbaum, which considers five factors affecting giftedness: general ability, special aptitude, environmental supports, non-intellective requisites (such as temperament or emotionality) and chance. The model is presented as a sea star diagram, with the area of giftedness in its centre.

Another developmental model is the concept of Jan Strelau (1997), a Polish psychologist who expanded Tannenbaum's model with a sixth factor - creative thinking. Strelau equates giftedness with a theoretical construct encompassing the relatively constant human traits which determine the quality of human performance. The author points to specific abilities in activities related to some narrow field, 
such as artistic, mathematical or highly specialised construction skills. This scope of above-average abilities, or high levels of ability, is equated with "giftedness" possessed by talented and exceptional children.

Even though constructing a uniform profile of a gifted child is an impossibility, researchers try to identify traits and behaviours displayed by particularly talented and creative students. Special needs of gifted children are another point of focus. Based on a review of research conducted by multiple authors, Limont (2012) distinguishes several groups of characteristics possessed by a gifted child: the first group comprises cognitive and domain-specific abilities, the second group - creativity, and the third group - personality traits. Children endowed with general or domain-specific giftedness often demonstrate unorthodox behaviour, which requires understanding, coupled with asynchronous development. Students with a high level of cognitive abilities stand out with their acuity of logical thinking. They exhibit rich vocabulary, a retentive memory, a facility for information seeking and the application of newly acquired knowledge, while the exceptionally gifted also have creative skills. Gifted children are often critical of their peers and teachers, as well as themselves. However, their traits and behaviours depend on their field of interest.

The profile of a gifted student may also be established by considering his or her characteristics in the scope of cognition, using the classification proposed by Danuta Czelakowska (2007). In the scope of cognitive activity, the author lists: curiosity about the world, ability to make detailed observations of the environment, inquisitiveness and openness to new experiences, intense intellectual activity, myriads of questions, a considerable base of extra-curricular information, particular directions of interests, passions and talents. In the scope of memory: rapid fact association, reasoning, and formulation of the right conclusions, excellent memory for content that interests the student and pertains to the presented problem, an eagerness to independently broaden his or her intellectual horizons, the ability to focus on interesting content for a long time. In the scope of imagination: interesting and original ideas, the observation of facts and phenomena undetectable to others, the need to express their own emotions and impressions in a variety of ways. In the scope of knowledge: a broad base of knowledge, rich vocabulary, independence and autonomy in formulating opinions. Since the presentation of the conducted research requires a reference to theory, the functioning of a gifted student is presented in three scopes: social, emotional and educational.

\section{SOCIAL FUNCTIONING OF GIFTED STUDENTS}

In discussing the social aspects of the socio-emotional development and functioning of gifted students, Tracy L. Cross and Jennifer Riedl Cross (2017) refer to the theory formulated by Erik Erikson. It views development as a progression through (stages) crises created by the tension between a person and his or her environment 
as the person gains new abilities and awareness. According to Erikson, the solution of the crises contributes to the development of a healthy ego, or the principal sense of "I". As children navigate across psychosocial crises, they develop considerable power fostering a strong ego, which is a factor in the development of giftedness and proper functioning in school settings. Erikson points to the necessity of maintaining a healthy balance between the desires and capabilities of the individual on one hand and his or her environmental support on another (Cross \& Cross, 2017).

In terms of interpersonal relations, gifted students are sometimes observed to be good leaders, but also to manipulate their peers with manifestations of dominating or submissive behaviour. "In social contacts, gifted students exhibit remarkable empathy and understanding for others and their needs on, one hand, but intolerance, excessive criticism of other people's mistakes, and often egocentrism on the other" (Dyrda 2008, p. 122). Atypical behaviour of gifted students meets with aversion, distrust, criticism, lack of kindness and even violence on the part of their peers. Research shows the increasing spread of violence, also towards gifted students, in the form of the so-called cyberviolence (MacFarlane \& Mina, 2018; Ronksley-Pavia et. al., 2018), which results in social isolation or even, in some cases, in suicides.

\section{EMOTIONAL FUNCTIONING OF GIFTED STUDENTS}

Research shows that gifted children exhibit emotional intensity, which is defined as having emotional reactions that are stronger, longer, more frequent, and more complex than those of an average person. As observed by Matthew J. Zakreski (2018) and previously established by other researchers, this phenomenon is accounted for by neurological differences. Elevated activity of the limbic system suggests that neurological functions in gifted persons are more heavily loaded with emotional content than in other children (Thompson \& Oehlert, 2010; Waisman et al., 2014, quoting Zakreski, 2018). Consequently, emotional imbalance in gifted children is not a rare occurrence. As revealed by the research of Joan Freeman (2008), it may be the consequence of inadequate emotional response of the parents to situations they find difficult with a gifted child.

The studies of Beata Dyrda (2012) showed that gifted children have little or no emotional self-control, exhibiting hyperexcitability or repression, sometimes combined with a low level of empathy. Irena Borzym's research (as in Limont, 2012) reveals that in comparison with control-group students, gifted children displayed higher neuroticism, sensitivity, lack of self-confidence, but high self-assessment and self-awareness. Gifted children may react to challenging situations with fear (Gaesser, 2018). The author notes that the fear may be episodic or chronic. The former case is triggered by a specific event or anxiety related to a particular moment during a lesson. Chronic cases are more persistent and long-lasting, often associated with the recurring worries or continuing situations (Limont, 2012, p. 187). 


\section{ACADEMIC FUNCTIONING OF GIFTED STUDENTS}

Gifted students are generally autonomous, independent, and well-organised in the performance of their school duties. They acquire knowledge and adapt to new conditions faster and easier than their peers. They also display greater flexibility in learning (Limont, 2012). On the other hand, they may not have developed the habit of regular work (Clark 1992, as in Dyrda, 2008). One could think that gifted students are top of their class, having academic achievements over and above those of their "average" peers. Yet, research shows (Dyrda, 2008, 2012) that as the students grow older, especially when they attend junior high school and high school, they start to underperform. This phenomenon is known as the Incommensurate School Accomplishment Syndrome (Dyrda, 2008, 2012; Limont, 2012). School accomplishments are associated with another phenomenon, or rather trait, exhibited by gifted students - perfectionism. Perfectionism has its bright and dark sides. As observed by Emily L. Mofield and Megan Parker Peters, "positive perfectionism (often referred to as positive striving, healthy, adaptive, or normal perfectionism) is a healthy pursuit of high standards and could be a driver of excellence, whereas maladaptive perfectionism (i.e. excessive worries, unhealthy, maladaptive, or neurotic perfectionism) brings discontent and anxiety" (Mofield \& Peters, 2018, p. 177). The pursuit of such inordinate standards may lead to the sense of guilt, disillusionment, heavy self-criticism, and avoidance of situations which carry a risk of making mistakes. It is worth mentioning that due to their high levels of ability, gifted students are often capable of excellence in given tasks. They are often praised and recognised for their exceptional academic accomplishments of talent, so their self-assessment tends to be linked with achievement.

The goal of the current study is to examine the in-class functioning of a gifted student attending a state primary school, based on the perception of teachers, parents and the gifted child. The main research problem may be encapsulated in the following question: How do gifted students function in class in the eyes of parents, teachers, and the students themselves? The issues at hand include:

1. How do gifted students function in the social dimension?

2. How do gifted students function in the emotional dimension?

3. How do gifted students function in the academic dimension?

\section{METHODOLOGY}

This study uses the qualitative strategy and an interpretational approach to analyse the functioning of a gifted student in the social, emotional, and academic dimensions as perceived by three groups of participants: gifted students, their parents and teachers. The participants were selected using non-probability sampling. The group of primary school students identified by their teachers as gifted included two second-grade students and one student from the third, fourth, fifth, and sixth 
grades, respectively. All students lived in a small Polish town (17 thousand inhabitants) where they attended the same school. Additionally, the study comprised interviews with the parents, although not in all cases could the interview be conducted with both parents. Empirical data was collected through qualitative, freeform, unstructured interviews recorded with a dictation machine upon the consent of the interlocutors. Instructions for interviews have been developed, separate for each type of student's functioning: social, emotional and educational. The interviews were conducted in convenient places. Some of the interviews were conducted in the home environments of the surveyed students, the remaining interviews were conducted at school (here mainly with students and teachers, as well as with some parents). They lasted from January to April 2018. The analysis involved the transcription of the interviews and the arrangement of data in the framework of special matrices representing the examined dimensions of functioning, separately for each student.

The study ${ }^{1}$ consisted of two stages. The first - preliminary - stage was aimed to acquire study participants. As noted above, the group was a non-probability, purposive sample. This method of sampling involved the selection of subjects who met the criterion posed in the research question (Rubacha, 2006). Selecting the study group required conversations with form teachers of grades 1-6 in the examined primary school, who nominated some ten to twenty gifted students. It was then necessary to obtain the consent of parents for the participation of the gifted child in the study. The willingness of the parents themselves to participate in the study was an additional requirement. Six teachers who worked with the selected gifted students also gave their oral consent. The names of the students were changed.

\section{RESULTS AND DISCUSSION}

For reasons of space, each student will not be characterised separately, though it could be interesting for the interpretation of results. The collected data will be presented in the matrices constructed according to the level of functioning in class.

\footnotetext{
${ }^{1}$ Research was conducted by one of the author's students as a project for her MA dissertation under the author's supervision.
} 
Table 1 An ordered matrix presenting the social functioning of the group. The issue is examined by comparing three perspectives (parent, teacher and gifted student)

\begin{tabular}{|c|c|c|c|c|c|c|}
\hline $\begin{array}{l}\text { Student } \\
(1-6)\end{array}$ & $\begin{array}{l}\text { Openness to } \\
\text { interpersonal } \\
\text { contact }\end{array}$ & $\begin{array}{l}\text { Preferred } \\
\text { types of } \\
\text { interpersonal } \\
\text { contact }\end{array}$ & $\begin{array}{l}\text { Situations of } \\
\text { contact }\end{array}$ & $\begin{array}{l}\text { Obstacles in } \\
\text { establishing } \\
\text { contact }\end{array}$ & $\begin{array}{l}\text { Perception } \\
\text { of others }\end{array}$ & $\begin{array}{l}\text { Perception by } \\
\text { others }\end{array}$ \\
\hline $\mathrm{S} 1$ & $\begin{array}{l}\text { Strong } \\
\text { withdrawal } \\
\text { from social } \\
\text { relationships } \\
\text { with peers. } \\
\text { Greater } \\
\text { openness to } \\
\text { relationships } \\
\text { with adults. }\end{array}$ & $\begin{array}{l}\text { Relationships } \\
\text { with adults } \\
\text { preferred. }\end{array}$ & $\begin{array}{l}\text { Group } \\
\text { work - a } \\
\text { necessity. }\end{array}$ & $\begin{array}{l}\text { Concern } \\
\text { about non- } \\
\text { acceptance; } \\
\text { sense of } \\
\text { rejection; } \\
\text { fear when } \\
\text { establishing } \\
\text { contact. }\end{array}$ & $\begin{array}{l}\text { Negative } \\
\text { attitude } \\
\text { to those } \\
\text { who don't } \\
\text { accept } \\
\text { or don't } \\
\text { like the } \\
\text { student. }\end{array}$ & $\begin{array}{l}\text { Swot, teacher's } \\
\text { pet, a person } \\
\text { who: always } \\
\text { keeps her nose } \\
\text { in the books; } \\
\text { can count } \\
\text { on special } \\
\text { treatment from } \\
\text { the teachers; } \\
\text { is an object of } \\
\text { envy. }\end{array}$ \\
\hline $\mathrm{S} 2$ & $\begin{array}{l}\text { High level of } \\
\text { openness to } \\
\text { interpersonal } \\
\text { contact. }\end{array}$ & $\begin{array}{l}\text { Considerable } \\
\text { ease in social } \\
\text { relationships } \\
\text { with peers } \\
\text { and adults } \\
\text { (outside } \\
\text { school with } \\
\text { the coach). }\end{array}$ & $\begin{array}{l}\text { The subject } \\
\text { uses all } \\
\text { situations, } \\
\text { including } \\
\text { those of } \\
\text { leadership, } \\
\text { to initiate } \\
\text { a social } \\
\text { relationship } \\
\text { with another } \\
\text { person. }\end{array}$ & $\begin{array}{l}\text { Disregard for } \\
\text { the student's } \\
\text { questions on } \\
\text { the part of } \\
\text { the teachers; } \\
\text { no sense of } \\
\text { humour on } \\
\text { the part of } \\
\text { the teachers; } \\
\text { lack of } \\
\text { understanding } \\
\text { for the } \\
\text { student's } \\
\text { sense of } \\
\text { humour. }\end{array}$ & $\begin{array}{l}\text { Noticing } \\
\text { strong } \\
\text { sides of } \\
\text { the other } \\
\text { person; } \\
\text { willingness } \\
\text { to stay in } \\
\text { contact } \\
\text { with } \\
\text { others. }\end{array}$ & $\begin{array}{l}\text { Much liked, } \\
\text { unconditionally } \\
\text { accepted, a } \\
\text { role-model, } \\
\text { unattainable } \\
\text { ideal. }\end{array}$ \\
\hline $\mathrm{S} 3$ & $\begin{array}{l}\text { Contact with } \\
\text { peers limited } \\
\text { to persons } \\
\text { who share } \\
\text { the student's } \\
\text { interest in } \\
\text { mathematics. }\end{array}$ & $\begin{array}{l}\text { Ease in } \\
\text { relationships } \\
\text { with known } \\
\text { people; } \\
\text { resistance to } \\
\text { establishing } \\
\text { new } \\
\text { relationships } \\
\text { (with adults } \\
\text { and peers). }\end{array}$ & $\begin{array}{l}\text { Situations } \\
\text { brought by } \\
\text { necessity } \\
\text { - the } \\
\text { requirement } \\
\text { to cooperate } \\
\text { with other } \\
\text { students; } \\
\text { answering } \\
\text { questions } \\
\text { from peers. }\end{array}$ & $\begin{array}{l}\text { Lack of } \\
\text { shared } \\
\text { interests and } \\
\text { conversation } \\
\text { topics; worry; } \\
\text { shyness; } \\
\text { sense of non- } \\
\text { acceptance; } \\
\text { unavailability. }\end{array}$ & $\begin{array}{l}\text { People } \\
\text { who envy, } \\
\text { don't } \\
\text { accept, } \\
\text { call names } \\
\text { such as } \\
\text { "swot", } \\
\text { "know- } \\
\text { all", } \\
\text { "weirdo". }\end{array}$ & $\begin{array}{l}\text { An unavailable, } \\
\text { withdrawn } \\
\text { person } \\
\text { functioning in } \\
\text { the inaccessible } \\
\text { world of his } \\
\text { own interests. }\end{array}$ \\
\hline
\end{tabular}




\begin{tabular}{|c|c|c|c|c|c|c|}
\hline $\begin{array}{l}\text { Student } \\
(1-6)\end{array}$ & $\begin{array}{l}\text { Openness to } \\
\text { interpersonal } \\
\text { contact }\end{array}$ & $\begin{array}{l}\text { Preferred } \\
\text { types of } \\
\text { interpersonal } \\
\text { contact }\end{array}$ & $\begin{array}{l}\text { Situations of } \\
\text { contact }\end{array}$ & $\begin{array}{l}\text { Obstacles in } \\
\text { establishing } \\
\text { contact }\end{array}$ & $\begin{array}{l}\text { Perception } \\
\text { of others }\end{array}$ & $\begin{array}{l}\text { Perception by } \\
\text { others }\end{array}$ \\
\hline S4 & $\begin{array}{l}\text { High level of } \\
\text { openness }\end{array}$ & $\begin{array}{l}\text { Very good } \\
\text { contact } \\
\text { with peers, } \\
\text { especially } \\
\text { those of the } \\
\text { opposite } \\
\text { sex; difficult } \\
\text { contact with } \\
\text { the form } \\
\text { teacher and } \\
\text { the English } \\
\text { teacher. }\end{array}$ & $\begin{array}{l}\text { Any } \\
\text { situation. } \\
\text { Requests for } \\
\text { help from } \\
\text { peers. }\end{array}$ & $\begin{array}{l}\text { With } \\
\text { students - a } \\
\text { dysfunctional } \\
\text { relationship } \\
\text { with one } \\
\text { female friend. } \\
\text { Motive: envy, } \\
\text { the desire to } \\
\text { dominate. } \\
\text { With teachers } \\
\text { - motive: } \\
\text { disregard } \\
\text { for the } \\
\text { student's own } \\
\text { knowledge } \\
\text { and the desire } \\
\text { to broaden it. }\end{array}$ & $\begin{array}{l}\text { Respect, } \\
\text { high } \\
\text { approval. }\end{array}$ & $\begin{array}{l}\text { Admiration, } \\
\text { recognition, } \\
\text { high approval. }\end{array}$ \\
\hline S5 & $\begin{array}{l}\text { High level } \\
\text { of openness; } \\
\text { considerable } \\
\text { ease. }\end{array}$ & $\begin{array}{l}\text { Peers and } \\
\text { teachers who } \\
\text { demonstrate } \\
\text { a curiosity } \\
\text { about the } \\
\text { student's } \\
\text { interests are } \\
\text { preferred. }\end{array}$ & $\begin{array}{l}\text { Any } \\
\text { situation. } \\
\text { Social } \\
\text { relationships } \\
\text { are } \\
\text { especially } \\
\text { intense if the } \\
\text { conversation } \\
\text { revolves } \\
\text { around the } \\
\text { student's } \\
\text { interests. }\end{array}$ & $\begin{array}{l}\text { With students: } \\
\text { a tendency } \\
\text { to hurl } \\
\text { accusations } \\
\text { and report on } \\
\text { others. With } \\
\text { teachers: } \\
\text { a lack of } \\
\text { interest in the } \\
\text { knowledge } \\
\text { and the } \\
\text { thirst for } \\
\text { knowledge } \\
\text { demonstrated } \\
\text { by the } \\
\text { student. }\end{array}$ & $\begin{array}{l}\text { Good pals, } \\
\text { people } \\
\text { who } \\
\text { support } \\
\text { and like } \\
\text { the student. }\end{array}$ & $\begin{array}{l}\text { Admiration, } \\
\text { recognition, } \\
\text { support, high } \\
\text { approval, } \\
\text { high level of } \\
\text { fondness. }\end{array}$ \\
\hline S6 & $\begin{array}{l}\text { Strong } \\
\text { withdrawal } \\
\text { from } \\
\text { relationships } \\
\text { with peers. }\end{array}$ & $\begin{array}{l}\text { Teachers, } \\
\text { significant } \\
\text { others } \\
\text { - parents. }\end{array}$ & $\begin{array}{l}\text { Academic } \\
\text { situations, } \\
\text { typical of } \\
\text { the school } \\
\text { setting, } \\
\text { which } \\
\text { require to } \\
\text { establish a } \\
\text { relationship; } \\
\text { answering } \\
\text { questions } \\
\text { from peers. }\end{array}$ & $\begin{array}{l}\text { Shyness; } \\
\text { fear and } \\
\text { concern about } \\
\text { establishing } \\
\text { any } \\
\text { relationships. }\end{array}$ & $\begin{array}{l}\text { Difficult } \\
\text { to assess; } \\
\text { positive } \\
\text { perception. }\end{array}$ & $\begin{array}{l}\text { Difficult to } \\
\text { assess; attempts } \\
\text { at establishing } \\
\text { a relationship } \\
\text { made by } \\
\text { the peers } \\
\text { are usually } \\
\text { unsuccessful. }\end{array}$ \\
\hline
\end{tabular}


Analysis of the empirical material shows that the social functioning of gifted students does not present a homogeneous picture and depends on their personality rather than giftedness. The examined group included gifted students who were very open, had the eagerness and aptitude for establishing relationships with their peers and teachers, and whose personality traits easily earned them the trust of others (Student 2; Student 4; Student 5). Three subjects showed limited relationships with peers (Student 1; Student 3; Student 6). In the case of students whose social performance in class could be described as positive, their activity in the school setting does not deviate in any manner from the functioning of their peers. Only occasionally, gifted students may count on greater admiration or interest in themselves or their abilities. The subjects exhibiting difficulties engaging in social relationships usually keep to themselves in the class setting, finding self-fulfilment in their passions and interest which make up for the frailty of their interpersonal relationships.

Coding the body of material gathered through interviews allowed us to identify the following categories of individual cases, defined metaphorically by the evaluation of their social functioning in class:

- Student 1: "a polyglot who keeps to the sidelines and observes the action in class".

- Student 2: "a football star who enjoys high recognition and always has lots to say".

- Student 3: "a mathematical thinker who takes appointments with petitioners in his den of interests".

- Student 4: "an unrivalled artsy celebrity admired by her fans, but also a good pal".

- Student 5: "a bundle of laughs with a scientific mind who annihilates all the worries of the class".

- Student 6: "a musical mind inaccessible to others".

Another research problem concerned the emotional functioning of gifted students. The collected data are presented below. 
Table 2 An ordered matrix presenting the emotional functioning of the group. The issue examined by comparison of three perspectives (parent, teacher and the gifted student)

\begin{tabular}{|c|c|c|c|c|}
\hline $\begin{array}{l}\text { Student } \\
(1-6)\end{array}$ & $\begin{array}{l}\text { Situations causing } \\
\text { particularly strong } \\
\text { emotions }\end{array}$ & $\begin{array}{l}\text { Coping with defeat: } \\
\text { strategies and } \\
\text { reactions }\end{array}$ & $\begin{array}{l}\text { Gifted student in a } \\
\text { successful situations: } \\
\text { reactions, feelings }\end{array}$ & $\begin{array}{l}\text { Resilience to } \\
\text { stress and difficult } \\
\text { situations }\end{array}$ \\
\hline $\mathrm{S} 1$ & $\begin{array}{l}\text { results incompatible } \\
\text { with the student's } \\
\text { expectations during } \\
\text { exams or competitions } \\
\text { - situations that } \\
\text { require demonstration } \\
\text { of knowledge }\end{array}$ & $\begin{array}{l}\text { crying, contact } \\
\text { avoidance; anger, } \\
\text { accusations, } \\
\text { verbal outbursts } \\
\text { (non-school } \\
\text { environment, } \\
\text { emotional release in } \\
\text { the home setting) }\end{array}$ & $\begin{array}{l}\text { joy experienced } \\
\text { stealthily, in solitude, } \\
\text { shared only with people } \\
\text { from outside the school } \\
\text { environment (the family } \\
\text { setting) }\end{array}$ & $\begin{array}{l}\text { low level of stress } \\
\text { resilience }\end{array}$ \\
\hline S2 & $\begin{array}{l}\text { development of an } \\
\text { interesting solution; } \\
\text { willingness to share } \\
\text { knowledge and ideas; } \\
\text { willingness to correct } \\
\text { erroneous knowledge } \\
\text { of peers }\end{array}$ & $\begin{array}{l}\text { defeat treated as a } \\
\text { natural experience } \\
\text { in education; the } \\
\text { student corrects } \\
\text { mistakes and } \\
\text { looks for the right } \\
\text { solutions }\end{array}$ & $\begin{array}{l}\text { joy which heightens the } \\
\text { physical activity of the } \\
\text { student }\end{array}$ & $\begin{array}{l}\text { stress as a } \\
\text { motivational } \\
\text { factor; in difficult } \\
\text { situations a return } \\
\text { to the gained } \\
\text { experience to } \\
\text { correct negative } \\
\text { episodes }\end{array}$ \\
\hline S3 & $\begin{array}{l}\text { public demonstrations } \\
\text { of knowledge; } \\
\text { performance in front } \\
\text { of the class }\end{array}$ & $\begin{array}{l}\text { every defeat treated } \\
\text { personally; often } \\
\text { hyper-emotionality, } \\
\text { exaggeration of the } \\
\text { problem }\end{array}$ & $\begin{array}{l}\text { joy experienced in } \\
\text { solitude }\end{array}$ & $\begin{array}{l}\text { feeling lost in } \\
\text { difficult situations; } \\
\text { need for support of } \\
\text { significant others }\end{array}$ \\
\hline S4 & $\begin{array}{l}\text { learning of her gaps } \\
\text { in knowledge; making } \\
\text { a mistake; negative } \\
\text { perception by peers }\end{array}$ & $\begin{array}{l}\text { defeats treated } \\
\text { personally; } \\
\text { nervousness; } \\
\text { effort to maintain } \\
\text { perfectionism }\end{array}$ & $\begin{array}{l}\text { vigorously } \\
\text { demonstrated joy }\end{array}$ & $\begin{array}{l}\text { ability to auto- } \\
\text { regulate and } \\
\text { combat stress } \\
\text { despite initial } \\
\text { concerns }\end{array}$ \\
\hline S5 & $\begin{array}{l}\text { mistakes; unsatiated } \\
\text { desire to share } \\
\text { knowledge }\end{array}$ & $\begin{array}{l}\text { sadness caused } \\
\text { by a defeat, slight } \\
\text { emotional agitation; } \\
\text { rational perception } \\
\text { of defeat as an } \\
\text { experience; search } \\
\text { for new solutions }\end{array}$ & $\begin{array}{l}\text { vigorously } \\
\text { demonstrated joy }\end{array}$ & $\begin{array}{l}\text { strong personality, } \\
\text { ability to auto- } \\
\text { regulate, search for } \\
\text { rational reasons, } \\
\text { and overcome } \\
\text { stress }\end{array}$ \\
\hline S6 & $\begin{array}{l}\text { interactions with peers } \\
\text { / the group }\end{array}$ & $\begin{array}{l}\text { exaggeration of the } \\
\text { problem; sadness; } \\
\text { automatic reaction: } \\
\text { crying }\end{array}$ & $\begin{array}{l}\text { good humour; latent } \\
\text { way of experiencing } \\
\text { success }\end{array}$ & $\begin{array}{l}\text { lack of resilience, } \\
\text { helplessness, } \\
\text { nervousness, } \\
\text { escape by bursting } \\
\text { into tears }\end{array}$ \\
\hline
\end{tabular}


The analysis of in-class emotional functioning of all study targets reveals that personality traits exhibited by students considerably affect their functioning in class, as well as in the emotional dimension. Above-average skills do not always go hand-in-hand with emotional resilience which helps to properly handle success and defeat, as well as cope with challenges and other difficult situations which confront gifted students with stress.

The factors causing specific emotional reactions of gifted students are highly individual and allow to perceive a wide array of possible nuances in the emotional functioning of gifted students in class. The coding of empirical material could be summarised in the following categories of functioning, described metaphorically: "A crybaby" - Student 1 and Student 6; "A self-sufficient motivator" - Student 2, Student 4 and Student 5 and "A lost loner" - Student 3.

Academic functioning of the examined gifted students includes the following categories:

1) academic activity during class (tasks, discussed content - individual / group character);2) student's motivation and commitment; 3) student's strategies to counteract boredom / lack of interest in the lesson.

As presented above, the category "school accomplishments" was not included in the matrix, although one may infer how the students unlock their potential from the opinions of their parents and teachers. Additionally, parents' comments on the academic functioning come from their children. Unfortunately, the issue of academic functioning cannot be presented in all the categories included in this scope. Therefore, in illustrating the perception in this dimension only the academic activity of the students will be discussed. 
Table 3 An ordered matrix presenting the academic functioning of the group. The issue examined by comparison of three perspectives (parent, teacher and the gifted student)

\begin{tabular}{|c|c|c|c|}
\hline $\begin{array}{l}\text { Student } \\
(1-6)\end{array}$ & Parents & Teachers & Student \\
\hline S1 & $\begin{array}{l}\text { Experience of boredom; growth } \\
\text { during English lessons. }\end{array}$ & $\begin{array}{l}\text { English teacher: always } \\
\text { brings separate worksheets } \\
\text { and materials for Student } 1 \text {. }\end{array}$ & $\begin{array}{l}\text { Experience of boredom, } \\
\text { extra activity during English } \\
\text { classes. }\end{array}$ \\
\hline S2 & $\begin{array}{l}\text { Focus on his interests: } \\
\text { mathematics and football; } \\
\text { studying comes easy to Student } \\
2 \text {, he has good grades but } \\
\text { devotes most of his energy to } \\
\text { football. }\end{array}$ & $\begin{array}{l}\text { Form teacher: quick } \\
\text { problem-solving; cheering. } \\
\text { Mathematics teacher: } \\
\text { Student } 2 \text { "works well; } \\
\text { whenever I can, I give him } \\
\text { extra exercises and ask him } \\
\text { to help others, so he does } \\
\text { some explaining". }\end{array}$ & $\begin{array}{l}\text { Difficulty in sitting in place; } \\
\text { "When the teacher shows } \\
\text { something new, I don't } \\
\text { get bored and listen"; "for } \\
\text { example, maths is cool, } \\
\text { because I have a lot of } \\
\text { interesting stuff to do". }\end{array}$ \\
\hline $\mathrm{S} 3$ & $\begin{array}{l}\text { Mathematics is his passion. He } \\
\text { completes maths problems for } \\
\text { older students. }\end{array}$ & $\begin{array}{l}\text { "He has remarkable skills, } \\
\text { completes junior-high-level } \\
\text { exercises even now". }\end{array}$ & $\begin{array}{l}\text { "I'm sitting and completing } \\
\text { exercises from the } \\
\text { handbook". }\end{array}$ \\
\hline S4 & $\begin{array}{l}\text { "The form teacher doesn't } \\
\text { really want my child to show } \\
\text { her talent; she functions in } \\
\text { class like any other child". }\end{array}$ & $\begin{array}{l}\text { Student } 4 \text { "is a very active } \\
\text { person, I often involve her } \\
\text { in school initiatives, and she } \\
\text { does a great job". }\end{array}$ & $\begin{array}{l}\text { "During class, I have to do } \\
\text { the same stuff as the others". }\end{array}$ \\
\hline S5 & $\begin{array}{l}\text { "Sometimes our son complains } \\
\text { that the teacher stopped him } \\
\text { from saying something. It's } \\
\text { probably when he talks too } \\
\text { much, because he can be a } \\
\text { handful - he does not get many } \\
\text { opportunities to share his } \\
\text { knowledge he has". }\end{array}$ & $\begin{array}{l}\text { When he receives extra } \\
\text { exercises in maths, he is } \\
\text { not restless; "he's hard to } \\
\text { contain". }\end{array}$ & $\begin{array}{l}\text { "If I'm acting out, Miss } \\
\text { gives me extra work, a sort } \\
\text { of worksheets; I complete } \\
\text { these and then we check } \\
\text { them together, so that I don't } \\
\text { get bored". }\end{array}$ \\
\hline S6 & $\begin{array}{l}\text { She "does great at school. } \\
\text { She's bashful. Lessons can be a } \\
\text { bore for her. She finds reading } \\
\text { materials from second-grade } \\
\text { handbooks ridiculous because } \\
\text { she already reads really serious } \\
\text { books". }\end{array}$ & $\begin{array}{l}\text { "A wise girl. And she's } \\
\text { working, she really is } \\
\text { committed more than most } \\
\text { children, she just does not } \\
\text { want to contribute or step } \\
\text { forward. She has a huge } \\
\text { problem with that". }\end{array}$ & $\begin{array}{l}\text { "I do the same exercises } \\
\text { as others. Only sometimes } \\
\text { the teacher will ask me } \\
\text { about something different, } \\
\text { something extra, when I } \\
\text { know a thing". }\end{array}$ \\
\hline
\end{tabular}

It may be observed that the statements of parents, teachers, and students concerning the category "academic activity of the student in class" contain some discrepancies. The academic functioning in individual cases may be portrayed in the following manner:

Student 1 (S1) - an unappreciated "lone diamond" allowed to shine only when it benefits the "kingdom". Student 1, a student with many talents, does not have many opportunities to unlock her potential in the course of her school experience. She often gets bored in class, and the academic offer proposed by the teachers dismally fails to meet the student's needs. The deficiency of the educational offer and the indifference of teachers to her talent dampen the girl's motivation and make her 
conform to the school's academic standards. School tends to limit the child's potential, showing temporary interest in her abilities only when they can be exploited in all forms of activity which improve the school's repute. Faced with the needs of the gifted student, teachers exhibit passivity. The only exception is the English teacher who strives to foster her pupil's talent.

Student 2 (S2) - an "analyst" with untapped potential for many disciplines who remains faithful to football and mathematics. Student 2, a student exhibiting above-average mathematical and sports skills, has the opportunity to develop and polish his potential in a school setting. The student focuses on the subjects he finds especially fascinating, showing maximum commitment to the activities for which he has a passion. He sometimes experiences boredom at school, which manifests in excessive agility. He can regain his focus when presented with interesting cognitive material. The student makes the most significant progress during mathematics classes, where he has highly customised conditions for work. The interviews with adults reveal that Student 2 does not use his potential to the fullest, even though the school is open to initiatives which would help him polish his skills.

Student 3 (S3) - "a talented mathematician" left to his own devices. Student 3 , as a mathematically gifted student with an individual education programme in the scope of mathematics, often deals with inadequate response to his educational needs. The school activity of the student is limited to completing the tasks presented by the teacher. The student does not always find the tasks attractive, but his inclination to comply with school requirements makes him follow the direction set by the teacher. The student makes far more significant progress in his mathematical skills outside school. These efforts bring noticeable results, which are often mistakenly interpreted by the school mathematics teacher as his own success.

Student 4 (S4) - "a hidden talent" which cannot be exposed in class. Student 4 is an artistically and linguistically gifted third-grade student who develops her above-average skills mostly outside school. The actions of her form teacher markedly impede her growth-oriented activity. Her only way to develop her abilities and her potential is to participate in extra classes at school. Those classes meet the cognitive needs of the students and allow her to foster her potential in the scope of linguistic and literary skills.

Student 5 (S5) - "a scientific mind" sometimes allowed to think and say more than others. An analysis of all the examined statements reveals that the boy does not get many opportunities to develop his over-average abilities at school. The emergence of such situations depends on the attitude of the teacher who prepares the tasks. The student has an enormous body of extra-curricular knowledge which he sometimes wishes to share with his peers, but the teacher sometimes objects. The lesson content tends to be unattractive to the student, and the lack of approval for his own knowledge leads to frustration. The boy's comments suggest that the 
teacher tries to foster the growth of her student, but her activity is mainly limited to pointing out additional content and checking the solutions.

Student 6 (S6) - "a musical talent which lies dormant (in the school setting)". Student 6, as a musically gifted child, cannot foster her talents in the school setting. Even though teachers are aware of the potential hidden in the student, they cannot do much to unlock it. High levels of ambition drive the girl consistently keep up with the school's curriculum. However, the presented content often fails to arouse her interest. As a result, the girl often experiences lassitude with the educational offer.

The analysis of individual cases presented above, however insufficient to draw general conclusions, can be discussed in a theoretical framework. Pupils included in the study exhibit typical traits of gifted children described by Czelakowska (2007), such as: curiosity about the world, ability to make detailed observations of the environment, inquisitiveness and openness to new experiences, intense intellectual activity, a considerable base of extra-curricular information, particular directions of interests, passions and talents.

In the social sphere of functioning, the examined students present various types of behaviour in relationships both with adults and peers. However, there was an observable preference for contact with adults, as noted in the literature (Limont, 2012). None of the students indicated violence, which may be related to the environment (a small-town school). The character of the study prevents constructing a uniform model of social functioning, which arises from the analyses, but allows several key conclusions to be drawn.

1. The social functioning of a gifted student significantly depends on the student's personality.

2. Openness and spontaneity in social relationships allow the student to make himself or herself known to the peers and help in gaining their acceptance.

3. Withdrawal from social relationships condemns the student to remaining unknown among the peers. As a result, the student is given socially constructed labels such as "swot", "know-all", "weirdo".

4. Gifted students inclined to withdraw from relationships with peers often have a better rapport with teachers and other adults. They may also prefer relationships with peers who share their interests. Gifted students who enter into social relationships spontaneously tend to have a good rapport with both peers and teachers.

5. Gifted students who avoid contact with peers in class often engage in communication only when necessary. For gifted students open to social relationships with others, every situation is an opportunity to establish contact.

Emotional functioning is often a clear reflection of the social performance of gifted students. In general, those who display openness to relationships with peers in class cope well with all types of emotional reinforcement experienced as they 
function in the class and school setting. Some cases reveal sensitivity and inability to handle emotions, such as lachrymosity (Student 1; Student 6), or a strong response to failure (Student 3). Some gifted students also get emotional when they have to perform in front of the class (Student 6) or deal with an imposed label of being gifted, often equated with the notion that the gifted student knows everything and has no right to make a mistake. Some students exhibit more mature behaviour in challenging situations (Student 2; Student 4; Student 5) such as self-motivation for growth.

With regard to academic functioning, these gifted students can be divided into three groups: I. - students who can develop their abilities in the school setting (Student 1 - English; Student 2 - mathematics), II. - students who only seemingly develop their abilities in the school setting (Student 3 - mathematics; Student 5 - mathematical and scientific education), III. - students unable to foster their talents in class (Student 6 - musical giftedness; Student 4 - linguistic and artistic giftedness - no opportunity to grow under the form teacher's supervision; potential opportunity to foster linguistic skills during extra classes in Polish under another teacher's supervision).

The functioning of any of the students in the educational dimension, similar to the other two dimensions, is a highly individual matter dependent on both external conditions (such as the attitude of the teachers; the school's approach to gifted education) and internal factors including personality considerations. Evidently, every gifted student is a complex individual who cannot be fitted into a single unchanging pattern. "We must insist that gifted students are served in curriculum models that work, delivered by trained teachers through pacing that reflects their readiness to learn and through advanced content that challenges them. If aspects of differentiated curriculum work for all learners, then it should be used with all. However, not all differentiated curriculum does work with all students." (VanTassel-Baska, 2019, p. 166). Joyce VanTassel-Baska (2019) proposes specific solutions for working with gifted students, but emphasizes only their educational functioning. It is important, but as the research presented here and the reports of other authors (Cross 2016; Cross \& Cross, 2017; Zakreski, 2018) show, the emotional and social functioning of gifted students is equally important and constitutes a real challenge for teachers.

\section{CONCLUSIONS}

In response to the research question, it needs to be noted that the functioning of gifted students in the perception of parents, teachers, and the students themselves in all dimensions: social, emotional, and educational, represents a complex and heterogeneous picture. Every child is an individuality, best known to the parents and himself or herself. Besides, research shows that students are aware of their giftedness and expect special treatment at school. The sporadic boredom and 
interruptions during lessons point to the fact that the teachers are not always willing to take on the challenge of working with gifted students. However, some teachers give examples of positive initiatives which produce a favourable effect on the students' functioning in the examined dimensions, as presented in tables 1,2, and 3 .

The pictures of the gifted students' functioning in individual spheres - social, emotional, and educational - may be referred to Renzulli's systems model. This framework considers the interaction between three basic clusters of human traits: above-average intelligence or above-average domain-specific abilities, high level of task commitment, and high level of creativity. Although no diagnosis was made in the scope of those dimensions, the perception of parents, teachers, and the self-awareness of the gifted students seem to confirm this interaction sufficiently. It appears that the pictures presenting the functioning of individual gifted students corroborate the theoretical findings, which point to the discrepancies in their performances. Those discrepancies result from the interaction of the factors discussed above and the impact of the external environment, which includes: organisational and economic capabilities and limitations of the local context typical of a small town, the school support system for gifted students and teachers and the attitude of teachers toward their talented children. However, it is worth emphasizing that qualitative research refers to a specific context - in this case, to the functioning of gifted students in a small town. Therefore, the results of the research cannot be generalized to the entire population of gifted students.

\section{REFERENCES}

1. Cross, T. L. (2016). Social and Emotional Development of Gifted Students. The Role of Contagion in Suicidal Behavior Among Students With Gifts and Talents. Gifted Child Today, 39(1), 63-66.

2. Cross, T. L., \& Cross, J. R. (2017). Social and Emotional Development of Gifted Students. Introducing the School-Based Psychosocial Curriculum Model. Gifted Child Today, 40(3), 178-182. https://doi.org/10.1177/1076217517713784

3. Czelakowska, D. (2007). Inteligencja i zdolności twórcze dzieci w poczatkowym okresie edukacji: rozpoznawanie i ksztatcenie. Oficyna Wydawnicza Impuls.

4. Dyrda, B. (2008). Twórczy uczeń w klasach początkowych - korzyści i bariery rozwojowe. Issues in Early Education, 1(7), 119-125.

5. Freeman, J. (2008). Emotional aspects of growing up gifted. Issues in Early Education, 1(7), 19-26.

6. Gaesser, A. H. (2018). Befriending Anxiety to Reach Potential Strategies to Empower Our Gifted Youth. Gifted Child Today, 41(4), 186-195. https://doi. org $10.1177 / 1076217518786983$

7. Gardner, H. (2002). Inteligencje wielorakie. Teoria w praktyce. Media Rodzina.

8. Giza, T. (2006). Socjopedagogiczne uwarunkowania procesów identyfikowania oraz rozwoju zdolności uczniów w szkole. Wyd. Akademii Świętokrzyskiej. 
9. Ledzińska, M. (2008). Fakty i mity na temat uczniów zdolnych. Issues in Early Education, (7), 49-58.

10. Limont, W. (1994). Synektyka a zdolności twórcze. UMK.

11. Limont, W., \& Cieślikowska J. (2004). Czy potrzebna jest pedagogika zdolności? In W. Limont (Ed.), Teoria i praktyka edukacji uczniów zdolnych (pp. 31-62). Oficyna Wydawnicza Impuls.

12. Limont, W. (2012). Uczeń zdolny. Jak go rozpoznać i jak z nim pracować. Gdańskie Wydawnictwo Psychologiczne.

13. MacFarlane, B., \& Mina, K. (2018). Cyberbullying and the Gifted Considerations for Social and Emotional Development. Gifted Child Today, 41(3), 130-135. DOI: $10.1177 / 1076217518768362$

14. Mofield, E. L., \& Peters M. P. (2018), Shifting the Perfectionistic Mindset. Moving to Mindful Excellence. Gifted Child Today, 41(4), 177-185. DOI: $10.1177 / 1076217518786989$

15. Nęcka, E. (2001). Psychologia twórczości. GWP.

16. Nęcka, E. (2003). Inteligencja. Geneza. Struktura. Funkcje. GWP.

17. Olszewski-Kubilius, P., \& Thomson, D. (2015). Talent Development as a Framework for Gifted Education. Gifted Child Today, 38(1), 49-59. https://doi. org/10.1177/1076217514556531

18. Partyka, M. (1999). Zdolni, utalentowani, twórczy. Poradnik dla pedagogów, psychologów, nauczycieli i rodziców: poradnik dla pedagogów, psychologów i nauczycieli. Centrum Metodyczne Pomocy Psychologiczno-Pedagogicznej Ministerstwa Edukacji Narodowej.

19. Ronksley-Pavia, M., Grootenboer, P., \& Pendergast, D. (2018). Bullying and the Unique Experiences of Twice Exceptional Learners Student Perspective Narratives. Gifted Child Today, 42(1), 19-35. https://doi.org/10.1177/1076217518804856

20. Rubacha, K. (2006). Metodologia badań nad edukacja. Akademickie i Profesjonalne.

21. Sisk, D. (1987). Creative Teaching of the Gifted. McGraw-Hill Book Company.

22. Strelau, J. (1997). Inteligencja człowieka. Akademickie ŻAK.

23. Uszyńska-Jarmoc, J., \& Kunat, B. (2018). Debiutant czy ekspert? Identyfikacja i samoocena uzdolnien uczniów. Oficyna Wydawnicza "Impuls".

24. VanTassel-Baska, J. (2019). Are We Differentiating Effectively for the Gifted or Not? A Commentary on Differentiated Curriculum Use in Schools, Gifted Child Today, 42(3), 165-167. https://doi.org/10.1177/1076217519842626

25. Zakreski, M.J. (2018). When Emotional Intensity and Cognitive Rigidity Collide. What Can Counselors and Teachers Do? Gifted Child Today, 41(4), 208-218. DOI: $10.1177 / 1076217518786984$ 


\title{
DAROVITI UČENICI U JEDNOJ POLJSKOJ ŠKOLI NA TEMELJU PERCEPCIJE UČITELJA, RODITELJA I DJETETA: INTERPRETATIVNO ISTRAŽIVANJE
}

\begin{abstract}
Sažetak: Ovaj rad istražuje socijalno, emocionalno i akademsko funkcioniranje darovitih učenika u razredu. Najprije se iznosi teorijski okvir problema počevši od njegova određenja i predstavljanja modela darovitosti. Zatim se raspravlja o funkcioniranju darovitih učenika iz perspektive drugih autora. Cilj je ovog istraživanja ispitati uspješnost darovitog učenika u razredu u odabranoj državnoj osnovnoj školi na temelju percepcije učitelja, roditelja i djeteta. Upotrijebljena je kvalitativna metodologija i interpretacijski pristup u istraživanju. Darovite učenike (šest slučajeva) predložili su njihovi razrednici. Empirijski podatci prikupljeni tijekom slobodnih i nestrukturiranih intervjua podvrgnuti su kvalitativnoj analizi. Nakon obrade podataka prikupljenih iz razgovora s roditeljima, učiteljima $i$ darovitim učenicima stvorena je slika o njihovu funkcioniranju. $U$ tu svrhu metaforičke kategorije darovitih učenika izrađene su odvojeno za svaki opseg (socijalni, emocionalni, akademski). U radu se analizira uspješnost darovitih učenika i uspoređuju rezultati s teorijskim pretpostavkama.
\end{abstract}

Ključne riječi: emocionalno funkcioniranje, modeli darovitosti, odgojno-obrazovno funkcioniranje, roditelji, socijalno funkcioniranje, učitelji 